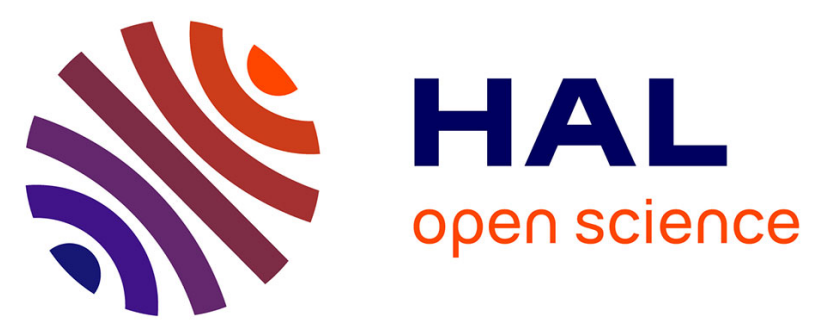

\title{
16O/18O isotopic exchange: A powerful tool to investigate oxygen activation on $\mathrm{M} / \mathrm{CexZr1-xO2}$ catalysts
}

Sumeya Bedrane, Claude Descorme, Daniel Duprez

\section{To cite this version:}

Sumeya Bedrane, Claude Descorme, Daniel Duprez. 16O/18O isotopic exchange: A powerful tool to investigate oxygen activation on M/CexZr1-xO2 catalysts. Applied Catalysis A: General, 2005, 289, pp.90-96. 10.1016/j.apcata.2005.04.016 . hal-00288424

\section{HAL Id: hal-00288424 https://hal.science/hal-00288424}

Submitted on 4 Feb 2022

HAL is a multi-disciplinary open access archive for the deposit and dissemination of scientific research documents, whether they are published or not. The documents may come from teaching and research institutions in France or abroad, or from public or private research centers.
L'archive ouverte pluridisciplinaire HAL, est destinée au dépôt et à la diffusion de documents scientifiques de niveau recherche, publiés ou non, émanant des établissements d'enseignement et de recherche français ou étrangers, des laboratoires publics ou privés.

\section{다(1) $\$$}

Distributed under a Creative Commons Attribution - NonCommerciall 4.0 International 


\title{
${ }^{16} \mathrm{O} /{ }^{18} \mathrm{O}$ isotopic exchange: A powerful tool to investigate oxygen activation on $\mathrm{M} / \mathrm{Ce}_{x} \mathrm{Zr}_{1-x} \mathrm{O}_{2}$ catalysts
}

\author{
Sumeya Bedrane*, Claude Descorme ${ }^{1}$, Daniel Duprez \\ Laboratoire de Catalyse en Chimie Organique UMR 6503, CNRS, Université de Poitiers 40, \\ Avenue du Recteur Pineau, 86022 Poitiers Cedex, France
}

Two series of metal catalysts ( $\mathrm{Rh}, \mathrm{Pt}, \mathrm{Pd}$, $\mathrm{Ru}$ and $\mathrm{Ir}$ ) supported over $\mathrm{CeO}_{2}$ and $\mathrm{Ce}_{0.63} \mathrm{Zr}_{0.36} \mathrm{O}_{2}$ were prepared. Catalysts were pretreated at 500 ${ }^{\circ} \mathrm{C}$ (fresh) and further sintered either in $\mathrm{H}_{2}$ or in air at $700-900{ }^{\circ} \mathrm{C}$. All catalysts were characterized by $\mathrm{H}_{2}$ chemisorption at $-85{ }^{\circ} \mathrm{C}$ and/or by transmission electron microscopy (TEM). The ${ }^{16} \mathrm{O}_{2}+{ }^{18} \mathrm{O}_{2}$ homoexchange reaction was carried out in the $200-500{ }^{\circ} \mathrm{C}$ temperature range. Rh, $\mathrm{Ru}$ and Ir showed the highest homoexchange rate $R$ (per $\mathrm{m}^{2}$ metal) while Pd and to a lower extent Pt were less active. Sintering affected the metal performances differently: while $R$ is higher on small $\mathrm{Rh}$ particles (fresh catalysts), the reverse situation could be observed for Ru and Ir where the sintered catalysts were more active than the fresh ones, especially in the case of $\mathrm{CeO}_{2}$.

Keywords: Isotopic exchange; Three-way catalysts; Oxygen activation; Rhodium; Platinum; Palladium; Ruthenium; Iridium; Ceria; Ceria-zirconia

\section{Introduction}

Ceria-zirconia oxides are now widely used in three-way catalysts (TWC) for the post-treatment of gasoline-fueled engines. Conventional TWCs mostly contain $\mathrm{Rh}, \mathrm{Pt}$ and/or Pd as the active phase and $\mathrm{Ce}_{x} \mathrm{Zr}_{1-x} \mathrm{O}_{2}$ as a support dopant to improve the oxygen storage capacity (OSC) of the catalyst. Such formulations simultaneously need to oxidize $\mathrm{CO}$ and the unburned hydrocarbons ( $\mathrm{HC}$ ) to $\mathrm{CO}_{2}$ and to reduce nitrogen oxides $\left(\mathrm{NO}_{x}\right)$ to $\mathrm{N}_{2}$. Optimal performances are obtained if the air-to-fuel ratio remains close to 14.6. This domain around the stoichiometry is called the "operating window". A closedloop injection system based on a lambda oxygen sensor allows regulating the oxidant-to-reducer ratio in the exhaust gas around the stoichiometry. However, under real driving conditions, this system generates long-term $(<0.1 \mathrm{~Hz})$ and short-term $(>1 \mathrm{~Hz})$ oscillations. So oxygen has to be stored during the oxygen-rich excursions and released when the

\footnotetext{
* Corresponding author. Present address: LCSCO, Université de Tlemcen, Département de Chimie, BP 119, 13000 Tlemcen, Algeria.

E-mail address: Sumeya.Bedrane@wanadoo.fr (S. Bedrane).

${ }^{1}$ Present address: Institut de Recherche sur la Catalyse, CNRS, 2 Avenue Albert Einstein, 69626 Villeurbanne Cedex, France.
}

oxygen partial pressure decreases. Cerium in ceria or ceriazirconia oxides, with a fast $\mathrm{Ce}^{4+} / \mathrm{Ce}^{3+}$ balance, was shown to be a good candidate for the oxygen transient storage.

Yao and Yu Yao [1] first introduced a method to measure the oxygen storage capacity of oxides. They evidenced the existence of two types of oxygen anions in $\mathrm{CeO}_{2}$ : a surface capping anion attached to a surface $\mathrm{Ce}^{4+}$ ion in an octahedral coordination and a bulk oxygen anion bonded to two $\mathrm{Ce}^{4+}$ ions. Since then, many papers were devoted to OSC measurements of ceria and ceria-containing materials [2-11].

More recently, Descorme et al. [12] evidenced the crucial role of oxygen-activated species (especially superoxides) in the whole process of the oxygen migration and storage. Well-dispersed noble metal particles would act as portholes for the subsequent diffusion of oxygen species on the support. Thus, the nature of the metal particles and the morphology of such metal particles have to be closely controlled if one wants to develop catalytic formulations with a faster response time.

For these reasons, in addition to $\mathrm{Rh}, \mathrm{Pt}$ and $\mathrm{Pd}$ usually used in TWCs, new active phases such as ruthenium and iridium can be tested. In fact, Nakatsuji [13] already reported the use of highly active Ir-based catalysts for the reduction of 
NO with hydrocarbons under lean conditions. Furthermore, Zeng and Pang [14] studied alumina-supported ruthenium catalysts for $\mathrm{N}_{2} \mathrm{O}$ decomposition with a high activity at $400{ }^{\circ} \mathrm{C}$, whereas, Sass et al. [15] used alumina supported ruthenium catalysts, containing $\mathrm{CeO}_{2}$, for the low-temperature $\mathrm{CO}$ oxidation. Nevertheless, Ru and Ir could not be incorporated in today's three-way catalysts because temperatures as high as $1000{ }^{\circ} \mathrm{C}$ can be reached in the catalytic converter. Under such conditions, volatile Ru and Ir oxides would form and lead to a rapid decrease of the metal content in the catalyst.

The aim of this work was the study of the oxygen adsorption/desorption on TWCs, the very first step of the oxygen storage process. ${ }^{16} \mathrm{O} /{ }^{18} \mathrm{O}$ isotopic homoexchange, developed by Duprez [16] was used to investigate the oxygen activation on the metal. The ability of Ru and Ir to activate oxygen will be checked and compared to that of $\mathrm{Rh}$, $\mathrm{Pt}$ and Pd. The present paper reports, for the first time, a parallel between the oxygen activation on several noble metals and the oxygen storage capacity. These experiments were carried out at medium temperature $\left(T<500{ }^{\circ} \mathrm{C}\right)$ to avoid any risk of $\mathrm{Ru}$ and $\mathrm{Ir}$ oxide volatilization during the catalyst pretreatment and testing.

\section{Principle}

As presented in Fig. 1, the oxygen exchange on metal supported catalysts might be decomposed in several steps:

- the dissociative adsorption of oxygen on the metal (1);

- the ${ }^{18} \mathrm{O}$ atoms spillover onto the support (2);

- the ${ }^{18} \mathrm{O}$ atoms migration towards the exchange sites (3);

- the exchange of ${ }^{18} \mathrm{O}$ atoms with ${ }^{16} \mathrm{O}$ atoms from the support (4);

- the back-spillover of exchanged atoms towards the metal and the desorption (6).

At higher temperature, depending on the support, bulk oxygen atoms may be exchanged (5) and even a direct exchange between the gas phase and the support (7) may take place.

The gas/solid isotopic exchange was widely investigated in the 1960s by Boreskov [17], Novakova [18] and Winter

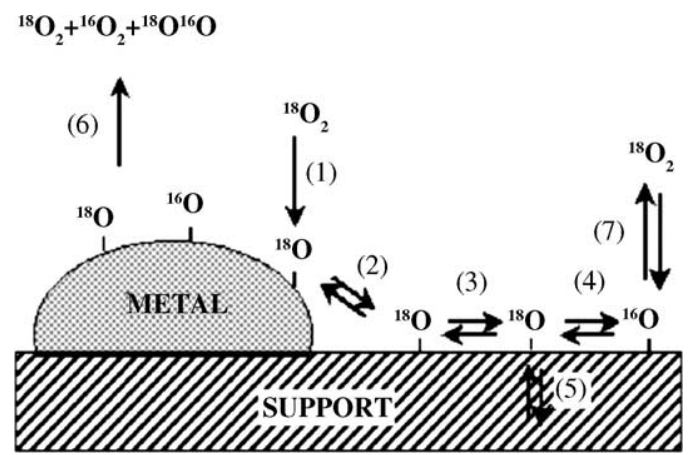

Fig. 1. General scheme of the oxygen isotopic exchange reaction.
[19]. These authors distinguished three types of reactions (Boreskov's nomenclature):

- simple heteroexchange (R);

- multiple heteroexchange $\left(\mathrm{R}^{\prime}\right)$;

- homoexchange $\left(\mathrm{R}^{\prime \prime}\right)$.

In the present work, the homoexchange reaction was only investigated. It consists of equilibration of a mixture of ${ }^{18} \mathrm{O}_{2}$ and ${ }^{16} \mathrm{O}_{2}$ in contact with the catalyst:

${ }^{16} \mathrm{O}_{2(\mathrm{~g})}+{ }^{18} \mathrm{O}_{2(\mathrm{~g})} \rightleftarrows 2{ }^{16} \mathrm{O}^{18} \mathrm{O}_{(\mathrm{g})}$

This reaction follows a simple mechanism (adsorption, recombination and desorption) and occurs on metal particles without any participation of the oxygen atoms from the support. Usually, metals are much more active than oxides for this reaction. Therefore, the homoexchange can be used to determine the global rate of the oxygen adsorption/ desorption on the metal, i.e. the ability of the metal to activate oxygen. As an example, the evolution of the oxygen isotopomers partial pressures upon isotopic homoexchange is reported in Fig. 2. The initial reaction rates, expressed in at. $\mathrm{m}_{\mathrm{M}}{ }^{-2} \mathrm{~s}^{-1}$ are given by:

$r_{\mathrm{q}}(t=0)=\frac{N_{\mathrm{g}}}{2 a_{\mathrm{M}} P_{0}} \frac{\mathrm{d}\left(P_{34}\right)}{\mathrm{d} t}$

where $N_{\mathrm{g}}$ is the total number of $\mathrm{O}$ atoms in gas phase, $P_{34}$ the ${ }^{16} \mathrm{O}^{18} \mathrm{O}$ partial pressure, $P_{0}$ is the total pressure $\left(P_{0}=P_{32}+P_{34}+P_{36}\right)$ and $a_{\mathrm{M}}$ is the metallic area of the sample.

\section{Experimental}

\subsection{Catalysts}

$\mathrm{M} / \mathrm{CeO}_{2}$ and $\mathrm{M} / \mathrm{Ce}_{0.63} \mathrm{Zr}_{0.37} \mathrm{O}_{2}$ catalysts were prepared by wet impregnation using the corresponding metal precursor solutions $\left(\mathrm{Rh}\left(\mathrm{NO}_{3}\right)_{3}, \mathrm{Pt}\left(\mathrm{NH}_{3}\right)_{4}(\mathrm{OH})_{2}, \mathrm{Pd}\left(\mathrm{NO}_{3}\right)_{3}\right.$, $\mathrm{Ru}(\mathrm{NO})\left(\mathrm{NO}_{3}\right)_{3}$ and $\left.\operatorname{Ir}\left[\mathrm{CH}\left(\mathrm{COCH}_{3}\right)_{2}\right]_{3}\right)$. In order to get the same metal atom percentage $\left(100 \mu \mathrm{mol} \mathrm{g}^{-1}\right)$, the metal

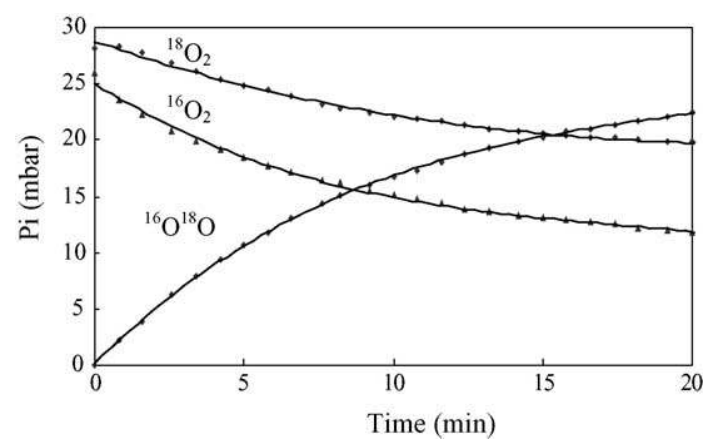

Fig. 2. Evolution of oxygen partial pressures as a function of time upon oxygen homoexchange reaction on $\mathrm{Pt} / \mathrm{CeO}_{2}$ catalyst at $350{ }^{\circ} \mathrm{C}$. 
loading was $1 \mathrm{wt} \%$ for $\mathrm{Rh}, \mathrm{Pd}$ and $\mathrm{Ru}$ and $2 \mathrm{wt} \%$ for Pt and Ir. Catalysts were dried at $120{ }^{\circ} \mathrm{C}$ for $24 \mathrm{~h}$ and pretreated for $4 \mathrm{~h}$ at $500{ }^{\circ} \mathrm{C}$ under flowing air or hydrogen $\left(30 \mathrm{~mL} \mathrm{~min}^{-1}\right)$. The metal dispersion was determined from the $\mathrm{H}_{2}$ chemisorption measurements, carried out at $-85^{\circ} \mathrm{C}$ to prevent any hydrogen spillover on the support [20]. The metal particle size was controlled by transmission electron microscopy (TEM) direct observations carried out in a CM 120 Philips microscope. The reduced samples were dispersed in ethanol, crushed to obtain very small grains and then collected on a $\mathrm{Cu}$ grid for direct observation. These catalysts were further treated at high temperature under oxidizing or reducing atmosphere in order to vary the metal particle size and morphology. The influence of these parameters on the oxygen storage and the oxygen activation were checked. The thermal pretreatment conditions are summarized in Table 1. Conditions were adjusted from one catalyst to another since we considered here the metal dispersion as the main selection criterion. However, it was not possible to obtain similar particle sizes for all sintered catalysts so that the effect of the metal dispersion on the homoexchange rates and on the OSC were compared on a qualitative basis.

\subsection{Oxygen storage measurements}

Oxygen storage capacities were measured according to the method developed by Yao and Yu Yao [1] and further adapted by Duprez and coworkers [2,6,21]. The sample is preheated under flowing $\mathrm{He}\left(30 \mathrm{~mL} \mathrm{~min}^{-1}\right)$ before oxidation at the reaction temperature. A sequence of alternating $\mathrm{CO}$ and $\mathrm{O}_{2}$ pulses was injected every $2 \mathrm{~min}$. OSC is determined from the amount of $\mathrm{CO}_{2}$ produced upon the first $\mathrm{CO}$ pulse and expressed in micromoles $\mathrm{CO}_{2}$ per gram of sample. The subsequent pulses allow a "regeneration" of the sample and a confirmation of the measured OSC value.

\subsection{Isotopic homoexchange experiments}

Isotopic homoexchange experiments were carried out in a homemade recycled reactor coupled with a Balzers QMS 420 mass spectrometer [22]. A $20 \mathrm{mg}$ sample was pretreated in situ at $400{ }^{\circ} \mathrm{C}$ as follows: 15 min oxidation under flowing ${ }^{16} \mathrm{O}_{2}, 15$ min outgassing, 15 min reduction under flowing $\mathrm{H}_{2}$, and finally, 30 min outgassing under primary vacuum $\left(10^{-3} \mathrm{mbar}\right)$. After the pretreatment, an equimolar mixture consisting of $25 \mathrm{mbar}{ }^{18} \mathrm{O}_{2}+25 \mathrm{mbar}{ }^{16} \mathrm{O}_{2}$ was introduced in the reactor at the reaction temperature. Partial pressures in ${ }^{18} \mathrm{O}_{2},{ }^{18} \mathrm{O}^{16} \mathrm{O},{ }^{16} \mathrm{O}_{2}, \mathrm{H}_{2} \mathrm{O}$ and $\mathrm{N}_{2}(\mathrm{~m} / \mathrm{z}=36,34,32,18,28)$ were recorded every second.

\section{Results and discussion}

\subsection{Metal dispersion of fresh and sintered catalysts}

The main textural and structural characteristics for the catalysts under study were reported earlier $[21,23]$.
The metallic phase dispersion was estimated using hydrogen chemisorption measurements and/or TEM direct observations. In the case of ruthenium and palladium catalysts, dynamic hydrogen chemisorption was not suitable [24]. For iridium catalysts, both methods were used to evaluate the metal particles size. Fresh catalysts were pretreated at $500{ }^{\circ} \mathrm{C}$. Catalysts sintering was obtained by treatment in $\mathrm{H}_{2}$ or in air at high temperature. Nevertheless, it was not possible to precisely adjust the particle size of all the sintered catalysts. The main results are reported in Table 1.

\subsection{Homoexchange over fresh catalysts}

For all the fresh catalysts, homoexchange reaction rates were measured at different temperatures between 200 and $500{ }^{\circ} \mathrm{C}$. The results are summarized in Fig. $3 \mathrm{a}\left(\mathrm{M} / \mathrm{CeO}_{2}\right)$ and Fig. $3 \mathrm{~b}\left(\mathrm{M} / \mathrm{Ce}_{0.63} \mathrm{Zr}_{0.37} \mathrm{O}_{2}\right)$ where the evolutions of the homoexchange rates (at. $\mathrm{m}_{\mathrm{M}}^{-2} \mathrm{~s}^{-1}$ ) as a function of temperature are reported in Arrhenius coordinates. In these figures, each point corresponds to a different measurement of the reaction rate for a given sample and a given temperature.

These results show that rhodium, ruthenium and iridium are the most active metals for the oxygen activation. Such metals already show a significant activity at temperatures as low as $200{ }^{\circ} \mathrm{C}$. On the opposite, palladium catalysts are much less active and no activity is observed below $350{ }^{\circ} \mathrm{C}$. Comparing the ability of the different metals to activate oxygen in the temperature range between 250 and $500{ }^{\circ} \mathrm{C}$, the noble metals under study can be classified as follows: $\mathrm{Rh}>\mathrm{Ru}>\mathrm{Ir} \gg \mathrm{Pt} \gg \mathrm{Pd}$.

For the isotopic homoexchange reaction, activation energies are summarized in Table 2.

For ceria-supported catalysts, activation energy is about $90 \mathrm{~kJ} \mathrm{~mol}^{-1}$ for $\mathrm{Pt}$, Ru and Ir catalysts and $210 \mathrm{~kJ} \mathrm{~mol}^{-1}$ for $\mathrm{Rh}$ and $\mathrm{Pd}$ catalysts. Such a difference is not observed for ceria-zirconia-supported catalysts $\left(110<E_{\mathrm{a}}<150 \mathrm{~kJ}\right.$ $\mathrm{mol}^{-1}$ ). Then, the modifications in the activation energies could not be related to the nature of the metal but more probably to the different metal/support interactions [25-27].

Table 1

Catalysts thermal treatment conditions and metal particles size

\begin{tabular}{lllllr}
\hline Catalyst & Fresh & & Aged \\
\cline { 2 - 3 } \cline { 5 - 6 } & Treatment & $d(\AA)^{\mathrm{a}}$ & & Treatment & $d(\AA)^{\mathrm{a}}$ \\
\hline $\mathrm{Rh} / \mathrm{CeO}_{2}$ & $4 \mathrm{~h}$, air, $500{ }^{\circ} \mathrm{C}$ & 10 & & $4 \mathrm{~h}, \mathrm{H}_{2}, 800{ }^{\circ} \mathrm{C}$ & 181 \\
$\mathrm{Pt} / \mathrm{CeO}_{2}$ & $4 \mathrm{~h}$, air, $500{ }^{\circ} \mathrm{C}$ & 12 & & $4 \mathrm{~h}$, air, $700{ }^{\circ} \mathrm{C}$ & 25 \\
$\mathrm{Pd} / \mathrm{CeO}_{2}$ & $4 \mathrm{~h}$, air, $500{ }^{\circ} \mathrm{C}$ & 12 & & $4 \mathrm{~h}, \mathrm{H}_{2}, 900{ }^{\circ} \mathrm{C}$ & 93 \\
$\mathrm{Ru} / \mathrm{CeO}_{2}$ & $4 \mathrm{~h}, \mathrm{H}_{2}, 500^{\circ} \mathrm{C}$ & 19 & & $4 \mathrm{~h}, \mathrm{H}_{2}, 800{ }^{\circ} \mathrm{C}$ & 29 \\
$\mathrm{Ir} / \mathrm{CeO}_{2}$ & $4 \mathrm{~h}, \mathrm{H}_{2}, 500^{\circ} \mathrm{C}$ & 24 & & $4 \mathrm{~h}$, air, $700{ }^{\circ} \mathrm{C}$ & 83 \\
$\mathrm{Rh} / \mathrm{Ce}_{0.63} \mathrm{Zr}_{0.37} \mathrm{O}_{2}$ & $4 \mathrm{~h}$, air, $500{ }^{\circ} \mathrm{C}$ & 15 & & $4 \mathrm{~h}$, air, $900{ }^{\circ} \mathrm{C}$ & 65 \\
$\mathrm{Pt} / \mathrm{Ce}_{0.63} \mathrm{Zr}_{0.37} \mathrm{O}_{2}$ & $4 \mathrm{~h}$, air, $500{ }^{\circ} \mathrm{C}$ & 12 & & $4 \mathrm{~h}$, air, $900{ }^{\circ} \mathrm{C}$ & 156 \\
$\mathrm{Pd} / \mathrm{Ce}_{0.63} \mathrm{Zr}_{0.37} \mathrm{O}_{2}$ & $4 \mathrm{~h}$, air, $500{ }^{\circ} \mathrm{C}$ & 15 & & $4 \mathrm{~h}$, air, $800{ }^{\circ} \mathrm{C}$ & 21 \\
$\mathrm{Ru} / \mathrm{Ce}_{0.63} \mathrm{Zr}_{0.37} \mathrm{O}_{2}$ & $4 \mathrm{~h}, \mathrm{H}_{2}, 500{ }^{\circ} \mathrm{C}$ & 13 & & $4 \mathrm{~h}, \mathrm{H}_{2}, 800{ }^{\circ} \mathrm{C}$ & 25 \\
$\mathrm{Ir} / \mathrm{Ce}_{0.63} \mathrm{Zr}_{0.37} \mathrm{O}_{2}$ & $4 \mathrm{~h}, \mathrm{H}_{2}, 500{ }^{\circ} \mathrm{C}$ & 32 & & $4 \mathrm{~h}$, air, $700{ }^{\circ} \mathrm{C}$ & 79 \\
\hline
\end{tabular}

${ }^{a}$ Metal particle size estimated from $\mathrm{H}_{2}$ chemisorption and TEM observations. 
Table 2

Activation energies of isotopic homoexchange reaction

\begin{tabular}{llrlrr}
\hline$E_{\mathrm{a}}\left(\mathrm{kJ} \mathrm{mol}^{-1}\right)$ & $\mathrm{Rh}$ & $\mathrm{Pt}$ & $\mathrm{Pd}$ & $\mathrm{Ru}$ & \multicolumn{1}{c}{$\mathrm{Ir}$} \\
\hline $\mathrm{CeO}_{2}$ & 210 & 90 & 210 & 90 & 90 \\
$\mathrm{Ce}_{0.63} \mathrm{Zr}_{0.37} \mathrm{O}_{2}$ & 130 & 130 & 130 & 150 & 110 \\
\hline
\end{tabular}

In fact, a strong metal/support interaction would lead to modifications in the electronic properties of the supported metals. As a result, not only the nature of the metal, but also the metal particle size, the particle morphology and the metal/support interactions do influence the oxygen activation process.

\subsection{Correlation between homoexchange and OSC}

Investigations about the oxygen storage process over such catalysts were already reported in a previous paper [21]. It was shown that $\mathrm{Rh}, \mathrm{Ru}$ and Ir were the most active metals to promote the oxygen storage. These results are significant since the oxygen activation on the metal particles is the first step in the oxygen storage process. At lowtemperature, oxygen storage is restricted to the metallic phase. It is then interesting to parallel oxygen storage capacities and homoexchange rates both measured at

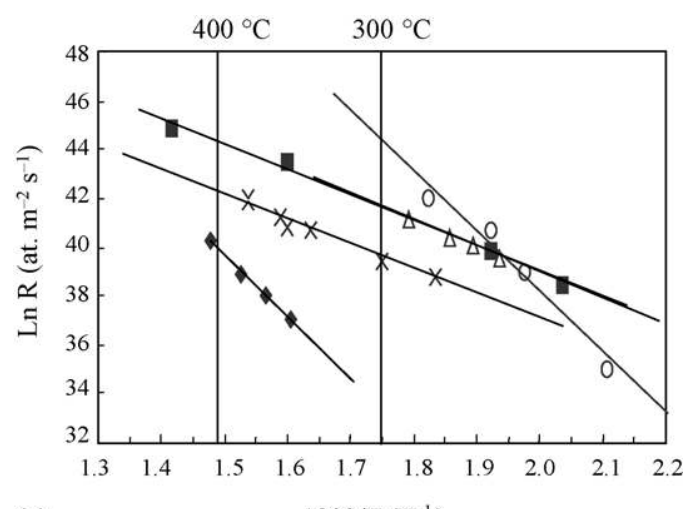

(a)

$1000 / \mathrm{T}\left(\mathrm{K}^{-1}\right)$

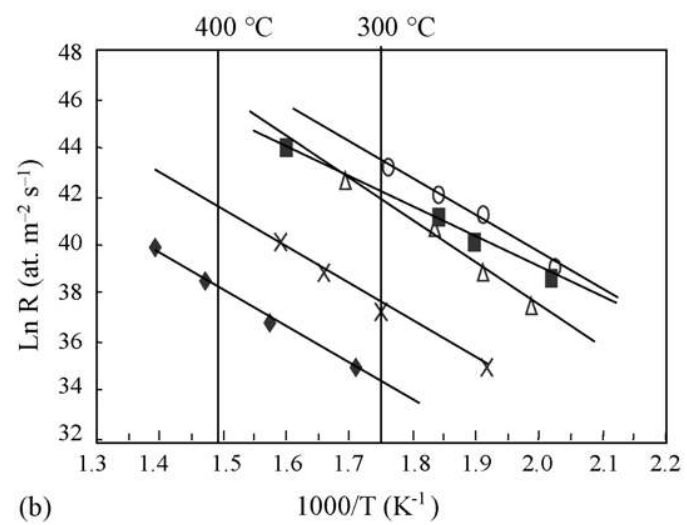

Fig. 3. Evolution as a function of temperature of homoexchange rates (at. $\mathrm{m}_{\mathrm{M}}{ }^{-2} \mathrm{~s}^{-1}$ ) on $\mathrm{M} / \mathrm{CeO}_{2}$ (a) and $\mathrm{M} / \mathrm{Ce}_{0.63} \mathrm{Zr}_{0.37} \mathrm{O}_{2}$ (b) catalysts with $\mathrm{M}=\mathrm{Rh}(\bigcirc), \operatorname{Pt}(\times), \operatorname{Pd}(\diamond), \operatorname{Ru}(\triangle), \operatorname{Ir}(\boldsymbol{\square})$
Table 3

Oxygen storage capacities and homoexchange rates measured at $200{ }^{\circ} \mathrm{C}$ on ceria-supported catalysts

\begin{tabular}{llllll}
\hline & $\mathrm{Rh} / \mathrm{CeO}_{2}$ & $\mathrm{Pt} / \mathrm{CeO}_{2}$ & $\mathrm{Pd} / \mathrm{CeO}_{2}$ & $\mathrm{Ru} / \mathrm{CeO}_{2}$ & $\mathrm{Ir} / \mathrm{CeO}_{2}$ \\
\hline $\begin{array}{l}\mathrm{OSC}-200 \\
\left(\mu \mathrm{mol} \mathrm{g}^{-1}\right)\end{array}$ & 127 & 84 & 63 & 164 & 274 \\
$\begin{array}{c}\text { R-200 } \\
\left(\text { at. } \mathrm{m}_{\mathrm{M}}{ }^{-2} \mathrm{~s}^{-1}\right)\end{array}$ & $2 \times 10^{15}$ & $3 \times 10^{15}$ & $2 \times 10^{10}$ & $21 \times 10^{15}$ & $24 \times 10^{15}$ \\
\hline
\end{tabular}

$200{ }^{\circ} \mathrm{C}$. Data for ceria-supported catalysts are reported in Table 3

Table 3 shows a good correlation between the oxygen storage capacities and the oxygen activation rates over ceriasupported catalysts. On one hand, ruthenium and iridium catalysts have both the greatest homoexchange rates and the greatest oxygen storage capacities at $200{ }^{\circ} \mathrm{C}$. On the other hand, palladium presents a much lower homoexchange rate and also a lower storage capacity. For such a metal, the oxygen desorption is the rate determining step in the homoexchange reaction. The same parallel between the OSC and the homoexchange rates was observed on ceriazirconia supported catalysts.

\subsection{Effect of sintering on homoexchange}

In order to check the influence of the metal particle size on the oxygen activation, the homoexchange reaction kinetics were measured for different metal dispersions. The main results are summarized in Fig. 4.

The influence of the metal particle size on the homoexchange reaction rate is reported for each metal and each support. Two different behaviors are observed depending on the nature of the metal:

- In the case of rhodium, the homoexchange rate decreases when the metal particle size increases. This is in agreement with the results reported by Duprez and coworkers. for rhodium catalysts supported on alumina and ceria-alumina [28,29]. This may be explained since small $\mathrm{Rh}$ particles are easily oxidized and oxygen desorption is easier from $\mathrm{Rh}_{2} \mathrm{O}_{3}$ compared to $\mathrm{Rh}^{\circ}$ [30,31]. Then, small rhodium particles should be more active.

- On the opposite, in the case of ruthenium and iridium, homoexchange rate increases with the metal particle size.

For platinum, the behavior seems to depend on the temperature range considered. In the case of $\mathrm{Pt} / \mathrm{CeO}_{2}$, at low-temperature, homoexchange reaction is faster on small particles. Beyond $400{ }^{\circ} \mathrm{C}$, homoexchange rate increases with the metal particles size. Taha also reported the same increase of the homoexchange rate with the platinum particles size on ceria and ceria-alumina catalysts [28]. For $\mathrm{Pt} / \mathrm{Ce}_{x} \mathrm{Zr}_{1-x} \mathrm{O}_{2}$, no significant effect of metal particle size is observed.

In the case of palladium, the influence of metal particle size on the homoexchange rate depends on the support. For 

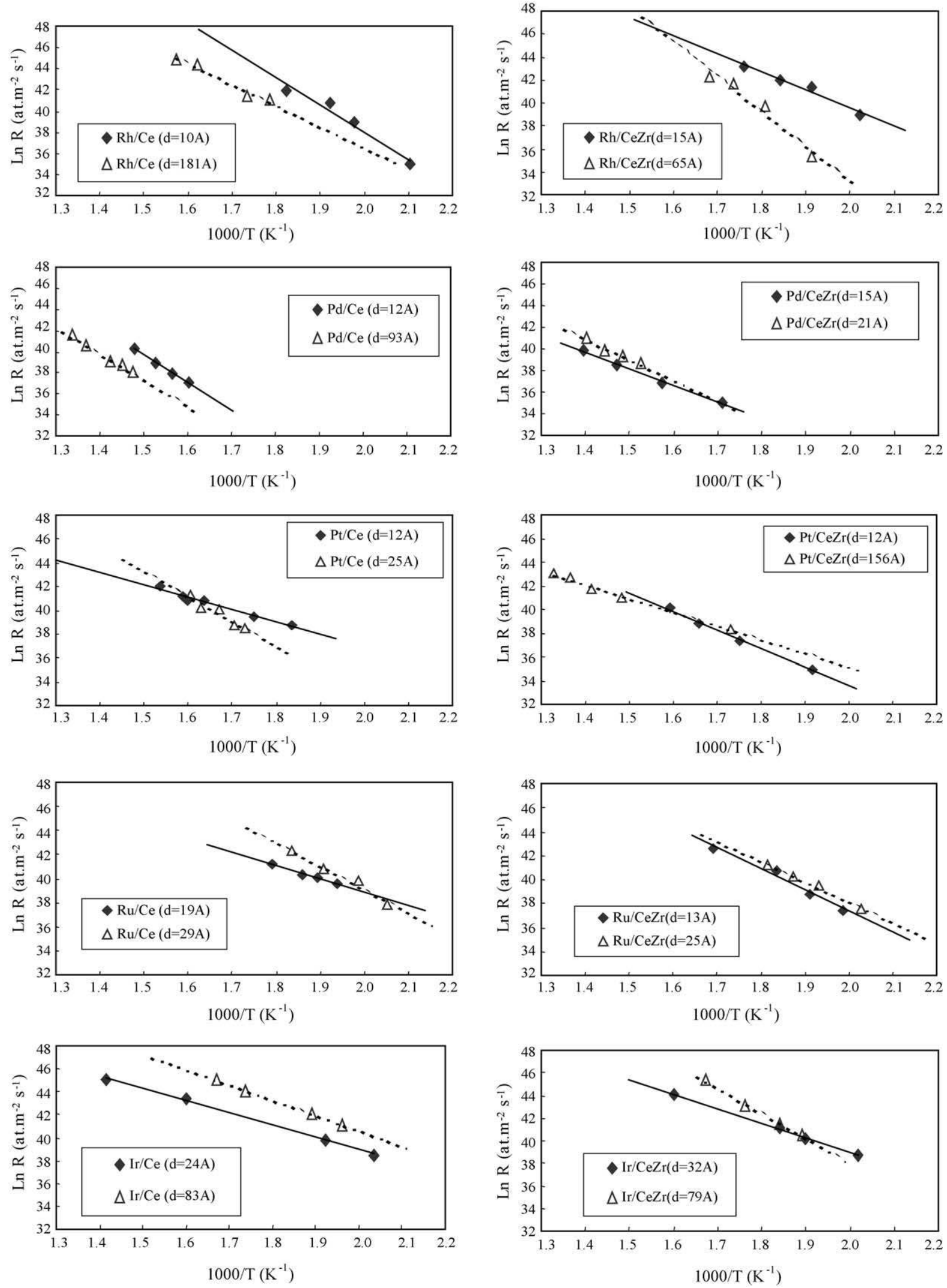

Fig. 4. Influence of metal particle size on homoexchange rate (at. $\mathrm{m}_{\mathrm{M}}{ }^{-2} \mathrm{~s}^{-1}$ ). Between brackets, metal particles size $d$ is expressed in $\AA$. 
$\mathrm{Pd} / \mathrm{CeO}_{2}$ catalyst, the homoexchange rate decreases when the metal particle size increases whereas for $\mathrm{Pd} / \mathrm{Ce}_{0.63} \mathrm{Zr}_{0.37} \mathrm{O}_{2}$, a small increase of the homoexchange rate is observed when the metal particle size increases. However, homoexchange reactions on palladium catalysts were carried out at relatively high temperature $\left(350{ }^{\circ} \mathrm{C}<T<500{ }^{\circ} \mathrm{C}\right)$. At such temperatures, the ceria and ceria-zirconia supports may participate to the exchange reaction and the support activity cannot be neglected anymore. Consequently, no definitive conclusion on the effect of the palladium particle size on the homoexchange kinetics could be drawn.

\subsection{Interpretation of the results: correlation with oxygen desorption}

In order to explain the different behaviors, rhodium on one hand and platinum, ruthenium and iridium on the other hand, earlier studies dealing with the oxygen adsorption/ desorption on well defined rhodium [32] and platinum $[33,34]$ surfaces can be paralleled with the present study. As relatively scarce data are available in the literature for $\mathrm{Ru}$ and Ir [35-37], we hypothesized the same interpretation as for platinum.

On one hand, Matsushimura studied the oxygen adsorption and desorption on rhodium polycrystalline surfaces [32]. Oxygen was previously adsorbed on $\mathrm{Rh}$ at low-temperature $\left(-148^{\circ} \mathrm{C}\right)$. When the temperature increased from -148 to $1077^{\circ} \mathrm{C}$, the authors observed two desorption peaks: (i) first peak at $110{ }^{\circ} \mathrm{C}$ corresponding to the adsorbed molecular oxygen and (ii) second desorption area (from 327 to $927^{\circ} \mathrm{C}$ ) attributed to the dissociatively adsorbed oxygens. Using labeled oxygen-18, the authors showed that the homoexchange reaction occurs exclusively when oxygen is dissociated on the surface. On the basis of these results, one could suggest that the decrease of the homoexchange rate on larger $\mathrm{Rh}$ particles is attributed to the poorer ability of such big particles, formed during the thermal treatment ( $4 \mathrm{~h}$ under $\mathrm{H}_{2}$ at $800{ }^{\circ} \mathrm{C}$ for $\mathrm{Rh} / \mathrm{CeO}_{2}$ ), to dissociate oxygen.

On the other hand, Gland [33] studied the oxygen desorption from platinum and evidenced two peaks, similar to those observed on rhodium. Moreover, Sobyanin et al. [34] showed that the oxygen homoexchange reaction on platinum is structure sensitive. The authors observed that the oxygen is more easily dissociated on $\operatorname{Pt}\left(\begin{array}{lll}1 & 1 & 1\end{array}\right)$ than on $\operatorname{Pt}\left(\begin{array}{lll}1 & 1 & 0\end{array}\right)$ while $\operatorname{Pt}\left(\begin{array}{lll}1 & 0 & 0\end{array}\right)$ is much less active. Then, these faces should not have the same activity in the homoexchange reaction. As a consequence, if one assumes that there is a uniform distribution of the prevalence of the three faces on the well dispersed catalysts $(D>50 \%)$, the fresh catalyst activity should correspond to the average activity of the three faces. After the thermal pretreatment, an increase of the (llll 111$)$ crystallographic face proportion on large particles is expected. In fact, this face has the lowest surface energy $[38,39]$. Then, if such a face is more active, the homoexchange reaction should be faster on large platinum particles.

\section{Conclusions}

The ${ }^{16} \mathrm{O}_{2}+{ }^{18} \mathrm{O}_{2}$ equilibration (homoexchange reaction) is a powerful technique to evaluate the oxygen activation process on metal catalysts. Whatever the support, rhodium exhibits a very high activity in the oxygen homoexchange reaction, especially when it is well dispersed. A similar behavior had already been observed for $\mathrm{Rh} / \mathrm{Al}_{2} \mathrm{O}_{3}$ and $\mathrm{Rh} /$ $\mathrm{CeO}_{2}-\mathrm{Al}_{2} \mathrm{O}_{3}$. Ru and Ir catalysts also show some excellent homoexchange activities. Nevertheless, Ru and Ir behave as Pt: bigger particles are more active than the smaller ones. $\mathrm{Rh}, \mathrm{Ru}$ and $\mathrm{Ir}$ are remarkably active between 200 and $300{ }^{\circ} \mathrm{C}$. Pt is almost one order of magnitude less active and $\mathrm{Pd}$ is virtually inactive below $350^{\circ} \mathrm{C}$. Differences in the oxygen desorption energies from the oxide surfaces and/or from the various crystallographic planes may explain the different metal behaviors.

\section{References}

[1] H.C. Yao, Y.F. Yu Yao, J. Catal. 86 (1984) 24.

[2] S. Kacimi, J. Barbier Jr., R. Taha, D. Duprez, Catal. Lett. 22 (1993) 343.

[3] P. Fornasiero, R. Di Monte, G. Ranga Rao, J. Kaspar, S. Meriani, A. Trovarelli, M. Grasiani, J. Catal. 151 (1995) 168.

[4] A. Trovarelli, Catal. Rev. Sci. Eng. 38 (1996) 439.

[5] R.W. McCabe, H.-W. Jen, W. Chun, G.W. Graham, L.P. Haack, A. Straccia, D. Benson, Appl. Catal. A: Gen. 84 (1999) 265.

[6] A. Holmgren, B. Andersson, D. Duprez, Catal. Appl. B: Environ. 22 (1999) 215.

[7] Y. Madier, C. Descorme, A.M. Le Govic, D. Duprez, J. Phys. Chem. B. 103 (1999) 10999.

[8] E. Rocchini, A. Trovarelli, J. Llorca, G.W. Graham, W.H. Weber, M. Maciejewski, A. Baiker, J. Catal. 194 (2000) 461.

[9] F. Fally, V. Perrichon, H. Vidal, J. Kaspar, G. Blanco, J.M. Pintado, S. Bernal, G. Colon, M. Daturi, J.C. Lavalley, Catal. Today 59 (2000) 373.

[10] M. Baoro, C. de Leitenburg, G. Dolcetti, A. Trovarelli, J. Catal. 193 (2000) 338.

[11] C. Descorme, D. Duprez, in: A. Trovarelli (Ed.), Catalysis by Ceria and Related Materials, Imperial College Press, 2002, pp. 243-280, Chapter 7.

[12] C. Descorme, Y. Madier, D. Duprez, J. Catal. 196 (1) (2000) 167.

[13] T. Nakatsuji, Appl. Catal. B: Environ. 25 (2000) 163.

[14] H.C. Zeng, X.Y. Pang, Appl. Catal. B: Environ. 13 (1997) 113.

[15] A. Sass, V.A. Shvets, G.A. Savel'eva, N.M. Popova, V.B. Kazanskii, Kinet. Katal. 27 (4) (1986) 894.

[16] D. Duprez, Stud. Surf. Sci. Catal. 112 (1997) 13.

[17] G.K. Boreskov, Adv. Catal. 15 (1964) 285.

[18] J. Novakova, Catal. Rev. 4 (1970) 77.

[19] E.R.S. Winter, J. Chem. Soc. A (1968) 2889.

[20] S. Bernal, F.J. Botana, J.J. Calvino, M.A. Cauqui, G.A. Cifredo, A. Jobacho, J.M. Rodriguez-Izquierdo, J. Phys. Chem. 97 (1993) 4118.

[21] S. Bedrane, C. Descorme, D. Duprez, Catal. Today 75 (2002) 401.

[22] D. Martin, D. Duprez, J. Phys. Chem. 100 (1996) 9429.

[23] S. Bedrane, C. Descorme, D. Duprez, Catal. Today 73 (2002) 233.

[24] S. Bedrane, C. Descorme, D. Duprez, J. Mater. Chem. 12 (5) (2002) 1563.

[25] S. Bernal, J.J. Calvino, G.A. Cifredo, J.A. Perez-Omil, J.M. Pintado, Catal. Today 23 (1995) 219. 
[26] S. Bernal, J.J. Calvino, J.M. Gatica, C. Larese, C. Lopez-Cartes, J.A. Perez-Omil, J. Catal. 169 (1997) 510.

[27] A. Trovarelli, Catalysis by Ceria and Related Materials, Catalytic Science Series, vol. 2, Imperial College Press, 2002.

[28] R. Taha, D. Duprez, J. Chim. Phys. 92 (1995) 1506.

[29] C. Descorme, D. Duprez, Appl. Catal. A 202 (2000) 231.

[30] D. Martin, D. Duprez, Appl. Catal. A 131 (1995) 297.

[31] E.P.J. Mallens, J.H.B.J. Hoebink, G.B. Marin, J. Catal. 167 (1997) 43.

[32] T. Matsushimura, J. Catal. 85 (1984) 98.

[33] J.L. Gland, Surf. Sci. 93 (1980) 487.
[34] V.A. Sobyanin, G.K. Boreskov, A.R. Cholach, A.P. Losev, React. Kinet. Catal. Lett. 27 (2) (1985) 299.

[35] V.P. Ivanov, G.K. Boreskov, V.I. Savchenko, W.F. Egelhoff, W.H. Weinberg, Surf. Sci. 61 (1976) 207.

[36] T.E. Madey, H.A. Engelhardt, D. Menzel, Surf. Sci. 48 (1975) 304.

[37] T. Engel, G. Ertl, Adv. Catal. 28 (1979) 1.

[38] J.K. McKenzie, A.J.W. Moore, F. Nicholas, J. Phys. Chem. Solids 23 (1962) 197.

[39] H. Wise, J. Oudar, Material Concepts in Surface Reactivity and Catalysis, Academic Press, 1990. 